\title{
POLITICAL THEORY
}

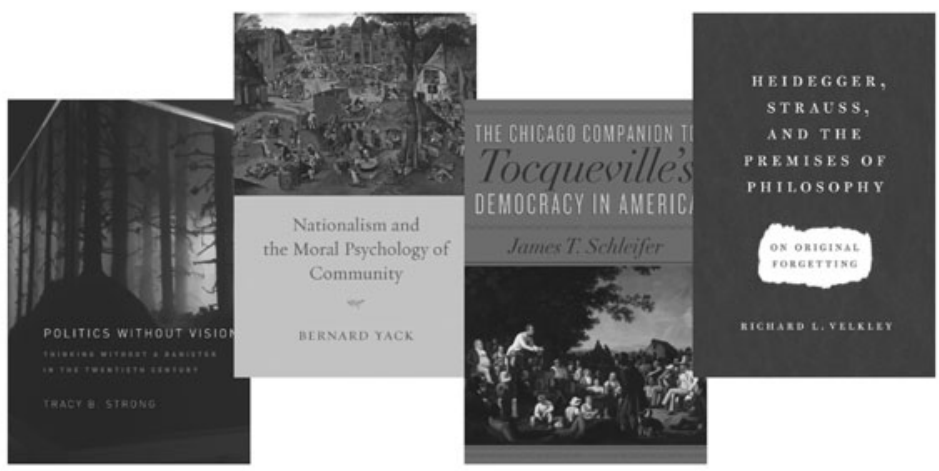

\section{Politics without Vision}

Thinking without a Banister in the Twentieth Century

\section{TRACY B. STRONG}

"I've been waiting for this book all my life. If Strong's aim is to look on the past with new eyes, then he is undoubtedly successful. Each chapter provides a heady mixture of intellectual energy, scholarly passion, and fresh perspectives."-Times Higher Education

Cloth $\$ 40.00$

\section{Nationalism and the Moral Psychology of Community BERNARD YACK}

"The content is original and insightful, sustained throughout by Bernard Yack's addressing of issue after issue, both in theoretical and practical terms, and doing so with enormous background knowledge of political theorists, past and present, and - crucially — with a sense of social reality."-John A. Hall, McGill University Paper $\$ 25.00$
The Chicago Companion to Tocqueville's Democracy in America JAMES T. SCHLEIFER

"Virtually everything one needs to know about Democracy, including a taste for Tocqueville's prose, is included in this fine companion."-Michael Kammen, Cornell University

Paper $\$ 15.00$

Heidegger, Strauss, and the Premises of Philosophy On Original Forgetting

\section{RICHARD L. VELKLEY}

"In brilliant fashion Velkley lays out a reading of Heidegger and Strauss that acknowledges the centrality of this neglected conversation to contemporary political thinking. ... A fresh, bold approach to timely philosophical questions." - Charles Bambach, University of Texas, Dallas

Cloth $\$ 40.00$

The University of Chicago Press www.press.uchicago.edu 


\section{POLITICAL THEORY}

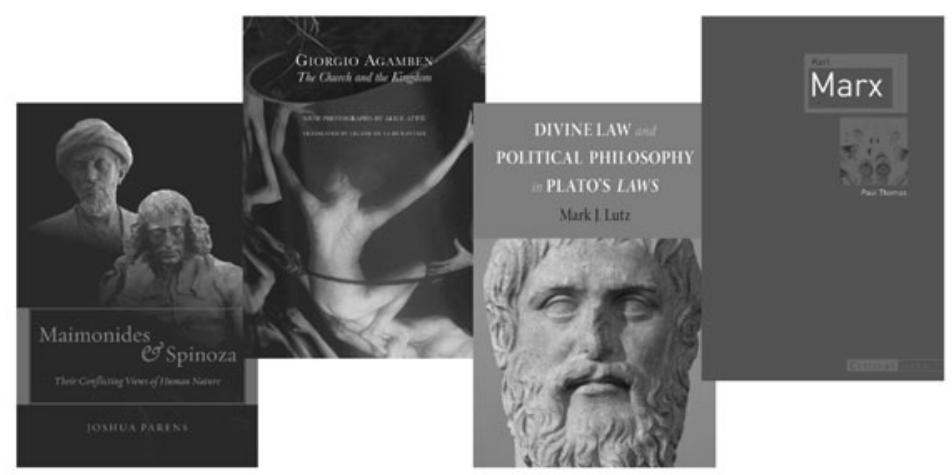

\section{Maimonides and Spinoza}

Their Conflicting Views of

Human Nature

\section{JOSHUA PARENS}

"Standing at the intersection between two fundamental problems - the relation between philosophy and religion, on the one hand; ancients and moderns, on the other-this book makes an important contribution to our understanding of each."

- Ronna Burger, Tulane University

Cloth $\$ 35.00$

From Seagull Books The Church and the Kingdom

\section{GIORGIO AGAMBEN}

Translated by Leland de la Durantaye, with Images by Alice Attie

Presenting an exegesis of certain key passages in the New Testament, Agamben examines the philology and philosophy at the root of the Church and of its earthly reign which are also the foundational texts of our modern idea of economy.

Cloth $\$ 20.00$
From Reaktion Books Karl Marx

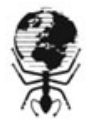
PAUL THOMAS

A valuable resource for anyone trying to understand the governments, wars, and movements of the twentieth and twentyfirst centuries, Karl Marx is an enlightening book about this potent thinker and the world that created him.

Paper $\$ 16.95$

From Northern Illlinois 茥 University NORTHERN Divine Law and Political Philosophy in Plato's Laws

\section{MARK J. LUTZ}

Mark Lutz argues that modern proponents of secular government have an important ally in Plato, whose long neglected Laws provides an eye-opening analysis of the relation between political philosophy and religion and a powerful defense of political rationalism.

Cloth $\$ 35.00$

The University of Chicago Press www.press.uchicago.edu 


\section{CAMBRIDGE}

\section{Outstanding Scholarship from Cambridge}

\section{Ideas in Context}

Montaigne and the Life of Freedom

Felicity Green

\$90.00: Hb: 978-1-107-02439-7: $272 \mathrm{pp}$.

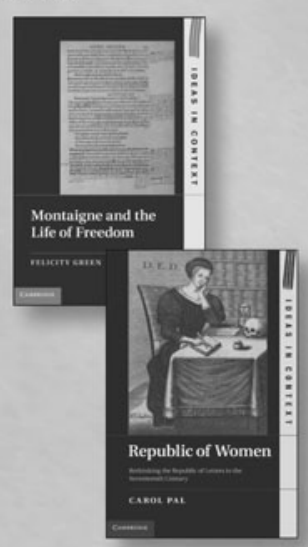

Republic of Women Rethinking the Republic of Letters in the Seventeenth Century

Carol Pal

\$90.00: Hb: 978-1-107-01821-1: $342 \mathrm{pp}$.

\section{Condorcet:}

\section{Political Writings}

Edited by Steven Lukes and Nadia Urbinati

Cambridge Texts in the History of Political Thought \$85.00: Hb: 978-1-107-02101-3 \$29.99: Pb: 978-1-107-60539-8: $262 \mathrm{pp}$.

\section{The French}

Enlightenment and the Emergence of Modern Cynicism

Sharon A. Stanley

\$90.00: Hb: 978-1-107-01464-0: $236 \mathrm{pp}$.

\section{Kant and}

\section{Cosmopolitanism}

The Philosophical Ideal of World Citizenship

Pauline Kleingeld

\$90.00: Hb: 978-0-521-76418-6: $232 \mathrm{pp}$.

The Soul of Nietzsche's Beyond Good and Evil

Maudemarie Clark and David Dudrick

\$99.00: Hb: 978-0-521-79041-3 \$29.99: Pb: 978-0-521-79380-3 $265 \mathrm{pp}$.

\section{The Cambridge} Companion to Existentialism

Edited by Steven Crowell Cambridge Companions to Philosophy

\$90.00: Hb: 978-0-521-51334-0 \$29.99: Pb: 978-0-521-73278-9: $428 \mathrm{pp}$.

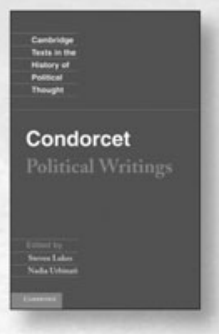

Thucydides and the Modern World

Reception, Reinterpretation and Influence from the Renaissance to the Present Edited by

Katherine Harloe and Neville Morley \$99.00: Hb: 978-1-107-01920-1: 280 pp.

\section{Modernity and Bourgeois Life} Society, Politics, and Culture in England, France and Germany since 1750 Jerrold Seigel \$95.00: Hb: 978-1-107-01810-5 \$29.99: Pb: 978-1-107-66678-8: $638 \mathrm{pp}$.

\section{Modern Pluralism}

Anglo-American Debates Since 1880

Edited by Mark Bevir \$95.00: Hb: 978-1-107-01767-2: $264 \mathrm{pp}$.

\section{The Political}

Construction of Business Interests

Coordination, Growth, and Equality

Cathie Jo Martin and Duane Swank

Cambridge Studies in Comparative Politics

\$99.00: Hb: 978-1-107-01866-2 \$31.99: Pb: 978-1-107-60364-6: $328 \mathrm{pp}$. 


\section{CAMBRIDGE}

\section{Outstanding Scholarship from Cambridge}

\section{Liberty before} Liberalism

Quentin Skinner

Canto Classics

\$16.99: Pb: 978-1-107-68953-4: $156 \mathrm{pp}$.

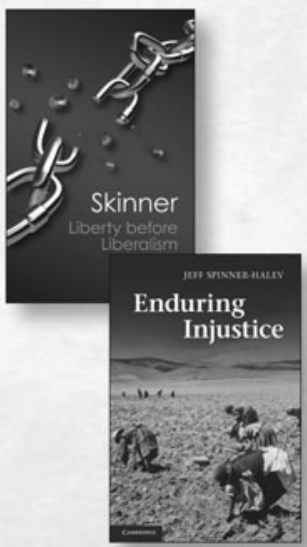

\section{Enduring Injustice}

Jeff Spinner-Halev

\$95.00: Hb: 978-1-107-01751-1 \$27.99: Pb: 978-1-107-60307-3: $246 \mathrm{pp}$.

\section{After War Ends}

A Philosophical Perspective Larry May

\$90.00: Hb: 978-1-107-01851-8 \$29.99: Pb: 978-1-107-60362-2: $258 \mathrm{pp}$.

\section{Ethics and War}

An Introduction

Steven P. Lee

Cambridge Applied Ethics

\$95.00: Hb: 978-0-521-89883-6 \$29.99: $\mathrm{Pb}: 978-0-521-72757-0$ $342 \mathrm{pp}$.

\section{New in Paperback!}

The Political Morality of Liberal Democracy

Michael J. Perry

\$32.99: Pb: 978-1-107-67238-3: $224 \mathrm{pp}$.

\section{The Foundations of Deliberative Democracy}

Empirical Research and Normative Implications

\section{Jürg Steiner}

\$99.00: Hb: 978-1-107-01503-6 \$34.99: Pb: 978-1-107-62501-3: $288 \mathrm{pp}$.

\section{Globalization and} Global Justice

Shrinking Distance, Expanding Obligations

Nicole Hassoun

\$85.00: Hb: 978-1-107-01030-7: $248 \mathrm{pp}$.

\section{International Relations} Theory and Regional

\section{Transformation}

\section{Edited by T. V. Paul}

\$99.00: Hb: 978-1-107-02021-4 \$34.99: Pb: 978-1-107-60455-1: $320 \mathrm{pp}$.

\section{Power and Willpower} in the American Future Why the United States Is Not Destined to Decline

Robert J. Lieber

\$90.00: Hb: 978-1-107-01068-0 \$24.99: Pb: 978-0-521-28127-0: $192 \mathrm{pp}$.

\section{Principles of Politics}

A Rational Choice Theory Guide to Politics and Social Justice

Joe Oppenheimer

\$99.00: Hb: 978-1-107-01488-6 \$32.99: Pb: 978-1-107-60164-2: $312 \mathrm{pp}$.

\section{Good Thinking}

Seven Powerful Ideas That Influence the Way We Think

\section{Denise Cummins}

\$70.00: Hb: 978-0-521-19204-0 \$22.99: Pb: 978-0-521-14550-3: $216 \mathrm{pp}$.

\section{The Cambridge Companion to Edmund Burke}

Edited by David Dwan and Christopher Insole

Cambridge Companions to Literature

\$80.00: Hb: 978-1-107-00559-4 \$27.99: Pb: 978-0-521-18331-4: $260 \mathrm{pp}$.

The Cambridge Introduction to George Orwell John Rodden and John Rossi

Cambridge Introductions to Literature

\$75.00: Hb: 978-0-521-76923-5 \$19.99: Pb: $978-0-521-13255-8$ : $148 \mathrm{pp}$.

Prices subject to change. 


\section{The President's Czars}

\section{Undermining Congress and the Constitution}

\section{Mitchel A. Sollenberger and Mark J. Rozell}

"Executive branch 'czars,' though much in the news, have been little studied or understood-until now. This important and timely book tackles the subject of executive 'czars' by placing them in legal, political, and historical context.

Thoroughly researched and strongly argued, it is the definitive source not only for understanding, but also for resolving, the constitutional ambiguities of this phenomenon."

-Robert J. Spitzer, author of Saving the Constitution from Lawyers

Studies in Government and Public Policy 312 pages, Cloth $\$ 39.95$, Paper $\$ 24.95$

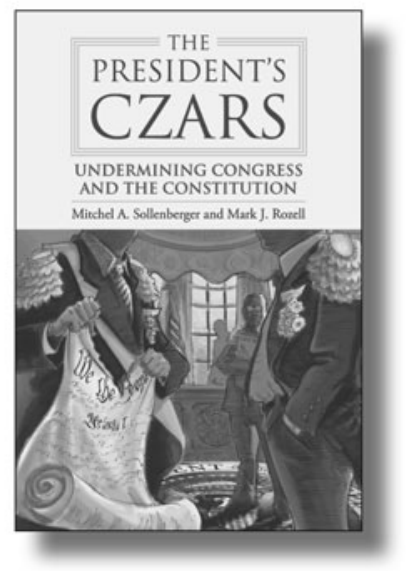

\section{Rush to Judgment}

\section{George W. Bush, the War on Terror, and His Critics}

\section{Stephen F. Knott}

"Knott offers a strong, well-researched account of Bush's policies, comparing his actions to those of other presidents in similar situations and pointing out that Bush acted well within the precedents set by other presidents. A much-needed corrective."-John Ehrman, coauthor of Debating the Reagan Presidency

"Knott provides a clear-eyed view of Bush's policies-and shows that much of the criticism and commentary of the Bush years was incoherent and hysterical." -Michael Barone, American Enterprise Institute

246 pages, 15 photographs, Cloth $\$ 29.95$

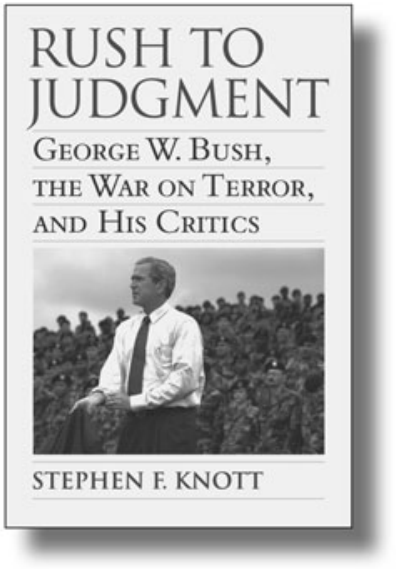

\section{University Press of Kansas}

Phone 785-864-4155 • Fax 785-864-4586 • www.kansaspress.ku.edu 


\section{The Review of Politics INSTRUCTIONS TO CONTRIBUTORS}

\begin{abstract}
AIMS AND SCOPE. The Review of Politics publishes primarily philosophical and historical studies of politics, especially those concentrating on political theory and American political thought. The journal also includes thoughtful scholarly reflections on all aspects of politics-including analysis of institutions and techniques, international relations, comparative politics, literary reflections on politics or political interpretations of literary works, constitutional theory and practices.
\end{abstract}

\section{MANUSCRIPT SUBMISSION AND REVIEW.}

To submit a manuscript for consideration please send an electronic file (formatted in MS Word):

\section{THE REVIEW OF POLITICS ONLINE SUBMISSION}

http://mc.manuscriptcentral.com/cup/rop

Complete instructions are provided on the website. The menu will prompt the author to provide all necessary information, including the manuscript category, contact information for the corresponding author (phone number, fax number, email address), and suggested reviewers. The website will automatically acknowledge receipt of the manuscript and provide a reference number. The Editor will assign the manuscript to anonymous reviewers and every effort will be made to provide the author with a review in a timely fashion.

Authors uncomfortable with online submission may send their manuscript as an email attachment to rop.editor.1@nd.edu or two hard copies plus a disk to:

Professor Catherine Zuckert

Editor, The Review of Politics

University of Notre Dame

547 Flanner Hall

Notre Dame, IN 46556

574-631-6623

ROP.Editor.1@nd.edu

www.nd.edu/ rop

BOOK REVIEWS. All correspondence regarding book reviews should be sent to Professor Peter R. Moody, Jr. at the above address.
MANUSCRIPT LENGTH. Normal length of published manuscripts is $8,000-11,000$ words. The entire manuscript, including notes and quotations, should be double-spaced.

Author anonymity. Because manuscripts are evaluated anonymously they should not bear the author's name or institutional affiliation. Please remove all references or acknowledgments that might indicate the identity of the author.

Abstract and keywords. All article submissions should include an abstract of 100-150 words.

\section{MANUSCRIPT PREPARATION AND \\ STYLE. The Review of Politics follows the Chicago Manual of Style for standards of citation, punctuation, and other editorial considerations.}

Figures and tables. Appendices, tables, and figures should be numbered consecutively throughout the article and be included on separate pages appearing after the reference section. Each figure must be submitted electronically as a separate file. Electronic versions should submitted as TIFF or EPS files at $100 \%$ of a suitable final size. Charts, graphs, or other artwork should be professionally rendered and computer generated.

\section{COPYEDITING AND PAGE PROOFS.}

The publisher reserves the right to copyedit and proofread all articles accepted for publication. Page proofs of an article will be sent to the lead author of an article for correction of typographical errors only; authors must notify the publisher or the editorial office of any changes within 72 hours of receipt of proof or approval will be assumed.

COPYRIGHT TRANSFER AGREEMENT. Papers with multiple authors are reviewed with the assumption that all authors concur with its submission. A Copyright Transfer Agreement, with certain specified rights reserved by the author, must be signed and returned to the Editor by senior authors of accepted manuscripts, prior to publication. The Review of Politics does not accept manuscripts for review that are under review elsewhere, previously published, or already committed for publication. 
Ian Shapiro, The Real World of Democratic Theory

Iris Marion Young, Responsibility for Justice

Leon Harold Craig, The Platonian Leviathan

Robert Meynell, Canadian Idealism and the Philosophy of Freedom

Louis Fisher, Defending Congress and the Constitution

... and more

Ruth Grant, "John Locke on Custom's Power and Reason's Authority"

Douglas Kries, "Tocqueville's Unfinished Manuscript on Ireland"

Anaïs Camus and Tristan Storme, "Schmitt and Tocqueville on the Future of the Political in Democratic Times"

Alex Zakaras, "A Liberal Pluralism: Isaiah Berlin and John Stuart Mill," with responses by George Crowder and William Galston

Cambridge Journals Online

For further information about this journal please go to the journal website at: journals.cambridge.org/rop 